\title{
PROFESSIONALISM OF ENGINEERS-BORDER GUARDS AS A FACTOR TO ACCOMPLISH THEIR SERVICE DUTIES
}

\section{Mykhailo Tomchuk}

\section{INTRODUCTION}

An important state task in the war in the east of Ukraine is the training of highly qualified specialists in the security and defense sector. Such a national task is successfully solved by the staff of the National Academy of State Border Guard Service of Ukraine (NASBGSU), providing professional training of cadets for future professional activity at the border. The formation of the competence and professionalism of future officers is directly connected with the development of their readiness to solve various tasks on the protection of the State Border of Ukraine. The professionalism of cadets-border guards, as an indicator of their personal readiness to complete their assignments, is formed at the academy as a special institution of higher education (HEI), in a holistic, integrated educational process. The level of professionalism depends on the objective (external) conditions, namely on the content and orientation of the educational process, the qualification of scientific and pedagogical staff, and on the individual characteristics of the cadets, their sensitivity, ability to learn, motivation, ability to regulate their mental conditions, behavior in the conditions of future extreme activity at the border, etc.

It is of scientific and practical interest to study the dynamics of personal readiness development to solve professional problems in the educational process of the State Border Guard Academy and in the process of adapting its graduates to real professional activity at the border. The development of components of person's professionalism, depending on the professional orientation of young people is still underdeveloped in psychology. That is why we have carried out a comparative analysis of the levels of development of individual components of professionalism in boys and girls studying in the academy and in humanitarian HEI. In the researches concerning the mentioned problem, insufficient attention is paid to the formation of professionalism of cadets-border guards - future engineers of the State 
Border Guard Service of Ukraine. They carry out the tasks that are relevant to the state: engineering support of the state border protection, maintaining communication between the border guard units, their software and technical service, etc.

The service of officers-engineers at the border takes place in special, conditions, requiring rapid adaptation of equipment, special devices to combat use, readiness for operational intellectual activity, planning, assumptions, making optimal decisions.

The young border guard-officer also needs a long time to adapt to the real life at the border, to fulfill his or her professional duties. The success of their adaptation is conditioned by the peculiarities of the development of the necessary personal, professionally significant qualities in the HEI.

The complication of the professional activities of military engineers at the border in the current environment requires the maximum use of content, innovative technologies for training the cadets to develop them as a creative personality, an individual who has prospects for improvement and is able not only to assess their capabilities adequately, but also to use them rationally in the future activities.

That is why the proposed study is devoted to theoretical and experimental analysis of the peculiarities of the development of border guard-engineers' professional readiness to solve their tasks.

\section{Professionalism as readiness of a person for professional activity}

Methodological basis in the process of studying the problem of professional forming of future engineers - the border guards-cadets was a personal activity, systematic approach. According to the activity approach (M. Ya. Basov, Ye. O. Klimov, O. M. Leontiev, S. L. Rubinshtein, V. D. Shadrikov, etc.), in the process of professional formation under the influence of educational, subject and professional activity, the border guard's personality changes, his motivation, competence, self-awareness.

Depending on the content and focus of training, a certain type of professional personality is formed at the National Academy of the State Border Guard Service of Ukraine, for example, future 
engineering officers show a slightly greater tendency to intellectual, technical activity.

The professional development of the individual is a two-sided process: firstly the profession, which is chosen, and the educational process in the HEI influence the development of the individual, and then the specialist make alterations to the professional activity at the state border.

According to the representatives of the systematic approach (L. K. Velitchenko, Yu. P. Povarionkov, V. V. Rybalka, etc.), professional formation of a person can be considered as a system "subject of work - professional activity". Thus, the psychological functional system of activity consists of motives of professional activity; goals that are related to the activity result, programs, information bases of the activity; decision making and subsystems of professionally important qualities. The structure of the subsystem of professionally important qualities changes and the level of their integration increases depending on the stage of professional formation $^{2}$. Professional formation is a dynamic systemic multilevel process: at its first level, mechanisms of socialization and individualization are studied; on the second - elements of the life path of the individual; on the third - mechanisms of development and learning; on the fourth - a form of personality activity. Professional formation of a person depends on social factors, professional abilities, professional experience, acceptance of "professionalization as a life task"3. An indicator of the person's professionalism is his readiness for professional activity. That is why we plan an experimental study of individual indicators of the border guards-engineers' readiness development to solve their service tasks: activity motives, volitional traits, qualities, etc.

${ }^{1}$ Povarenkov Yu. P. (2002). Psykholohycheskoe soderzhanye professyonal'noho stanovlenyya cheloveka [Psychological content of professional formation of a person]. Moscow: Publishing House of URAO. [in Russian]

${ }^{2}$ Shadrikov V. D. (1996). Psykholohyya deyatel'nosty y sposobnosty cheloveka [Psychology of human activity and ability]. Moscow: Logos Publ. [in Russian]

${ }^{3}$ Povarenkov Yu. P. (2002). Psykholohycheskoe soderzhanye professyonal'noho stanovlenyya cheloveka [Psychological content of professional formation of a person]. Moscow: Publishing House of URAO. [in Russian] 
Within the systematic approach, scientists distinguish the components of professional activity: needs, motives, subject matter, information base, purpose, tools, social environment and subject. In accordance with this model, a two-dimensional model of personality (subject of professional activity) is revealed, the personality's structure of general psychological properties has been revealed in the following dimensions: social-psychological and individual (psychosociality, capability to communicate, determination, character, self-awareness, experience, intellect, psychophysiology, psychosomatics) and activity (need-motivational, informative-cognitive, goal-forming, operationaleffective, emotional-sensual components) ${ }^{4}$.

The person formation in a professional activity, success is largely dependent on an adequate comparison of oneself, one's own achievements in the profession with those ones of others. The professional activity of a specialist in the subjective dimension and, accordingly, its formation is revealed through the achievement of professional suitability, through readiness for activity, which implies the subject's compliance with its requirements. The stages of professional formation are: preparation for the profession, option, vocational training, mastery of professional activity, skills, leaving the profession. We consider that very important periods are the choice of profession, vocational training and the stage of mastering and adapting to it. The subject of our study is to study the peculiarities of professionalization of cadets in the educational process of HEI and in the process of adaptation and mastery of graduates with professional engineering activities in the initial period of service at the border.

Professional development is understood as the formation of a set of integrated personality characteristics: professional orientation, competence, socially and professionally important qualities, as well as its readiness for constant professional growth, finding the correspondence between individual-personality characteristics and the nature of pursuing professional activity with the aim of more qualitative and creative approach to its implementation. During the implementation

${ }^{4}$ Rubalka V. V. (2014). Psykholohiya ta pedahohika pratsi osobystosti: vid obdarovanosti dytyny do maysternosti dorosloho [Psychology and pedagogy of the work of the individual: from the gifted child to the skill of the adult]. Kyiv: Institute of Gifted Child Publ. [in Ukrainian] 
of professional activity, there is an interaction of the person and the profession, which causes the corresponding changes: on the one hand, under the influence of activity, a person changes, on the other hand - the nature and content of the profession transforms. The main contradiction contributing to the development of personality is the mismatch between the requirements of the profession and the available personality traits. Therefore, with the inclusion of a person in professional activity is enriching his psyche due to the formation of complexes of qualities. Determinants of professional formation are external influences (socioeconomic conditions) and internal conditions (peculiarities of the psyche of the individual, his social and professional experience). The decisive importance in professional development belongs to professional activity, which depends on the quality of professional activity, getting pleasure from it, the pace of professional growth, the possibility of overcoming professional crises, etc. 5

The crises overcoming in ontogenesis is caused by the driving forces of personality development, provided they are resolved productively. We believe that the subject of activity for effective professional development must go through overcoming contradictions and crises. Much of this depends on the activity of the individual, the level of his motivation to perform professional activity, readiness for self-realization and so on.

The study of the psychological structure of activity, including the professional one, helps to solve extremely important methodological and practical problems and answer the following questions: 1) how the objective world transforms during the active intervention of a person to perform professional activity; 2) how a person changes during the performance of a certain activity; 3) the appearance of the psychological structure of any particular professional activity; 4) how the activity influences the development of human capabilities and how the activity itself becomes individual ${ }^{6}$.

${ }^{5}$ Zeer E. F. (2009). Psykholohyya professyonal'noho obrazovanyya [Psychology of Professional Education]. Moscow: IT Academy Publ. [in Russian]

6 Bodrov V.A. (2007). Psykholohycheskye osnovy professyonal'noy deyatel'nosty [Psychological bases of professional activity]. Moscow: PERSE Publ. [in Russian] 
Typical tasks and skills are identified for each profession, which imply not only specific professional knowledge, skills, but also professionally important personality traits (PITs). Today, in our opinion, it is important to distinguish the concepts of professional competencies of the engineer, which imply not only his knowledge, skills, abilities, but also the ability to use them in new non-standard conditions, to include the intelligent, volitional qualities to solve pressing problems of engineering activities.

In general, in the readiness for professional activity of a future engineer, the following components can be distinguished: motivational, cognitive, individual-typological, operational-procedural and emotional-volitional, which have their own characteristics. Each component of the professionalism of a future engineer is characterized by specific features. Thus, the motivational component includes the presence of developed motivation to obtain professional knowledge and skills, mastering engineering activities, and expressed motives (creative implementation, motivational units for military service, process, educational and cognitive motives, etc.), also an important aspect is the ability to set an adequate goal and find the means to achieve it, and in general, to the profession as a satisfying one.

The cognitive component is primarily the knowledge of the profession of military engineer, professional intelligence (technical thinking, imagination), which have specific properties that allow you to solve engineering problems, and its structure includes the idea of themselves in the profession as such characteristics, which imply awareness, interpretation, self-description and situations that occur around you. The individual-typological component contains the typological and characterological properties of the engineer's personality, including PSF. Emotional-volitional readiness is characterized by the personality's ability to manifest volitional qualities, stress resistance, self-regulation of behavior and activity, emotional states in conditions of high extremality of activity at the border. In operational readiness, the skills and competencies, which are necessary for the border guard, are singled out, the ability to use professional experience in border operations; personal potential that determines the effective performance of professional tasks; creativity that provides high-quality non-template solution to professional problems. 
Thus, under the professionalism of future military engineers we understand the psychological formation of a cadet's personality, which is an integrative characteristic of a subject of engineering activity, the basis of which is professional authenticity, which contains not only professional competence but also reflects a high level of development of professionally important qualities, which provide professionally important qualities, progressive development of future border guards of engineering and technical specialties at the stage of vocational training.

\section{Psychological analysis of the activities of border guard-officers of the engineering direction}

The professional engineering of officers at the border is complex and multifunctional. Readiness for it is enshrined in the educational process at NASBGSU. The development of future border guards-engineers is ensured in the course of mastering the cadets in 1-2 courses of knowledge and skills in general and humanities, basic disciplines and, above all, in mathematics, physics, materials science, material resistance, electrical engineering, etc. Based on this, they master the basics of content and organization of transportations, economics of operation and military repair of equipment in the State Border Guard Service, organization of economic work in the military unit on the operation and repair of motor vehicles, transportation, technical and economic indicators of technical condition and works of motor transport, use of the main production assets of the unit, use of its working capital, economics of material-technical security basics reduce the cost of operation and repair of automotive and special equipment etc.

The special task of training border guards is to teach them the features of the organization, the operation of weapons and equipment, and the order and analysis of the reliability of the basic samples of border equipment. In terms of content, such training includes the features of the operation of weapons and special equipment, the operation and accounting of motor vehicles, the control of the state of arms and military equipment at the border, theoretical foundations and the calculation of indicators of their reliability.

The border guard-engineer must also have good knowledge of the basics of engineering support for the protection of the state border at 
the sector of the border guard detachment and the use of technical means of monitoring it. He must be well-informed in the basic types of technical support for units (tank, artillery, etc.). In terms of content, this involves knowledge of the basics of tank and technical support, the features of weapons and equipment in the conduct of hostilities, methods of planning repair of weapons and equipment in the conduct of combat operations, the evacuation of weapons and equipment, providing armed vehicles and equipment, units of the border guard detachment, general provisions on artillery and technical support, system of providing troops with rocket artillery and ammunition, bases of artillery and technical support of troops, provision of parts of missile and artillery weapons and ammunition in the main types of combat, artillery and technical support of the border guard detachment, engineering and technical support in main types of combat actions.

The general actions and actions of border guards include: deciding on the use of force and means; planning of border protection measures; setting tasks for border guards to protect the state border; organization of management, interaction and comprehensive support; preparation of detachments to repel enemy attacks and support them in constant combat readiness, control over the implementation of all border protection measures in the conditions of hybrid war and others.

The combat service of the border guards and, above all, the officers, involves performing difficult functions related to the high efficiency, dynamic action of the units, maintenance and use of sophisticated modern equipment, automated control systems, information processing and intelligence.

Particularly specific in terms of psychology is the organization of combat service of military personnel in extraordinary circumstances. It covers a number of such basic measures: assessment of the current situation, determination of the required number of forces and means for defense, use of the State Border Guard Service of Ukraine (SBGSU) with the highest efficiency, etc.

Educational function of the service and combat activity of the officer of the SBGSU is to train personnel in the actions during the performance of combat tasks, actions on alarms: to organize and conduct tactical and tactical-special, instructive training with personnel, which have details, use weapons and military equipment, summarize the combat service in the unit, prepare and conduct training 
with military personnel on combat readiness, constantly check the status of combat readiness of those techniques and weapons in the assigned units, use in the military service different types and forms of training and education of subordinates.

Service-combat activity is also characterized by complex conditions, which are naturally reflected on the mental level of the individual in the form of anxiety, fears, stresses, etc. The reasons for the appearance of such conditions of the border guards are:

1) suddenness, unexpectedness of occurrence and manifestation of different situations of combat service;

2) threat to the person's normal life and health;

3) danger to life and health;

4) unusuality and novelty of situations;

5) uncertainty (complete or partial lack of information, inconsistency of the combat situation);

6) redundancy of information (in case of excess of information on certain events of the phenomenon, there is a need for deep and accurate analysis and drawing of adequate conclusions);

7) lack of time (to analyze, evaluate the situation, make decisions and take specific actions, as border guards have very little time in comparison with the usual conditions of activity);

8) responsibility (for the execution of orders, according to the statutes, employees are legally responsible; in addition, they are charged with high social, moral responsibility for their actions and actions);

9) awareness of the SBGSU personnel of the special nature and results of combat service;

10) officers, ensigns, and soldiers endure prolonged difficulties, discomfort, and sometimes even indignation associated with the lack of proper living conditions.

Such activity is intense and places special demands on the emotional-volitional sphere of the individual. According to M. I. Diachenko, V. O. Ponomarenko and others, situations of special stress can be characterized by the following types (quoted $\mathrm{in}^{7}$ ):

7 Tomchuk M. I., Matohniuk L. O. (2012). Formuvannya psykholohichnoyi hotovnosti osobystosti do inzhenernoyi diyal'nosti na zanyattyakh z matematyky [Formation of psychological readiness of an individual for engineering activities in mathematics classes]. Vinnitsa: Publisher FOP Rogalskaya I. O. [in Ukrainian] 
1. Rapid situation. The activity is carried out in the conditions of severe shortage of time with the maximum mental load, the readiness of the person for immediate action at an extremely fast pace. Such situations in combat activity are characterized by unexpectedness, speed of occurrence and course, lack or contradiction of information, intensity of intellectual functions (thinking, imagination and others).

2. Long-lasting. In such a situation, high physical and mental endurance, mobilization, responsibility and autonomy are important for military personnel. These are situations in anticipation of certain behavior of border violators, etc.

3. The situation with the element of uncertainty. In such a situation, the military man faces the problem of choosing the only correct solution from several possible equally socially significant options.

4. A situation that requires an individual's readiness for urgent, operational action. In this situation, special requirements are taken into account, the speed of psychic functions, emotional balance.

5. Situation related to the receipt of false information. The way out depends on the amount of such information, the availability of time to process it and the professional experience of the border guard.

6. The situation of a "dominant state" in the activity of a military man is related to his being in a state of weak reaction to the teams, signals that can lead to negative consequences of the activity.

7. Critical situation. It occurs in extreme cases of activity of military personnel and gives them an alternative choice of possible results of activity: victory or complete defeat. In such a situation, all the possibilities and reserves of the individual are revealed, and their adaptive capabilities are revealed. Such situations are a criterion for checking the military personnel for their position, social status.

That is why the important task of forming the cadets' psychological readiness for future activity at the border is the formation of the necessary volitional qualities, the ability to selfregulate their states, behavior under different conditions of professional activity mentally.

Psychological analysis of the modern activities of the border guard shows that it can be presented to some extent as human life in special, more extreme, compared to his activity in many other areas, conditions of existence. This is a strictly regulated and controlled 
activity of the individual. It goes with certain moral, social, temporal, spatial, and more restrictions. In the service itself, formal relations are strictly and normatively regulated, employees are not allowed to be members of any parties, they cannot participate in the work of various mass meetings, organizations, societies.

In today's SBGSU, compared to the past times, there are significant changes in the direction of its decision:

1) the share of mental labor in use has increased due to its greater intellectualization and new scientific research, scientific and technical developments, means implementation;

2) certain reorganizational changes in the structure, the content of the activity of different SBGSU units;

The activity of the SBGSU has its specific socio-psychological features, which largely determine and require complication of the subjective psychological structure of the activity of the border guard's personality.

They are the following:

1) great social and state importance of the activity;

2) high physical, intellectual and emotional tension, pace and dynamics of the service;

3) more rigid, in comparison with other professions, the regulation and legal regulation of the relations between its participants;

4) the ability to perform duties in different climatic, weather, time intervals, etc.;

5) high degree of collective activity;

6) high level of organization of relationships vertically and horizontally;

7) frequent change of some activities, actions to others, which may be caused by different operational situation, etc.

Subjective conditions for pursuing professional activity at the border should also include the level of personal awareness of one's mental properties, qualities, degree of development of mental cognitive processes, emotional and volitional sphere, psychomotor, the level of knowledge, skills, and in general - abilities, which allow for timely and adequate conclusions.

The SBGSU officers should have a well-formed organizational component of the activity, which is revealed in the following features: 
1) self-organization, manifested in discipline, proper distribution of time, clear fulfillment of various duties;

2) organization of activities of other persons, who perform homogeneous or different functions in the team;

3 ) organizing and coordinating the activities of other units, institutions that perform service functions in certain situations.

Military engineers create, maintain in working order military machines, mechanisms, devices, process various materials. They must be able to understand the drawings and diagrams, to represent not only the device and the static state of the mechanism, machine, but also the process of working interaction, the movement of their elements, parts. It is important to be able to build versions of the possible causes of disorders, problems, and in the imagination to reproduce the search options, highlighting the most likely, and, most of all, in the special conditions of activity. Particularly sophisticated knowledge is required in the field of properties of objects of work, conditions and means of their transformation, it is also important to know perfectly the structure and functions of used military machines, devices, tools. It is necessary to have a lot of knowledge and quantitative indicators related to the modes of operation of equipment, its operation, working conditions. High demands apply to all forms and types of memory, thinking. Especially often requires a clear imaginary operation of objects in space, understanding the principles of operation, operation of machines, mechanisms, circuits, electronic and electrical devices. Military engineers are also appreciated for their ability to make optimal decisions in the short term. It requires emotional restraint, stability in emergencies, increased sense of responsibility (the cost of error when working with equipment is very high).

As a result of the survey of graduates of the Academy (more than 200 people), we can distinguish the following features of the professional activities of border guard-engineers: mental load, creativity, experience and knowledge, organization, initiative, autonomy, responsibility. However, the productivity of professional activities of engineers, largely depends on their personal, including volitional qualities, on the degree of their formation and manifestation. Among the professionally important personal qualities of engineers we have identified such as: readiness for independent work, professional communication, working capacity, self-organization, self-improve- 
ment, self-control, creative, spatial imagination, a tendency for technical creativity, tension, self-regulation, courage in making; promptness; teamwork, organization, discipline; compromise thinking, the ability to find an alternative between the idea of designers and the real possibilities of implementation of this idea in life; accuracy, attentiveness; stress resistance; persistence; engineering thinking.

The performance of the engineering activity is realized through the implementation of production functions that are generally typical of the engineer. They include:

1. Research, which is related to the implementation of research works, work with scientific materials and literature;

2. Design, which involves the development and design of new types of products, improvement of equipment and decision-making methods;

3. Technological, which is associated with the choice of technological process, control of the production process, in general with the control of technological systems.

Understanding these functions ensures the implementation of the professional program of the engineer. An important element of the psychological structure of engineering activities is decision making and their possible correction. This is due to the development of mental self-regulation of the personality of the officer of his volitional qualities. The study of these features, among others, will be the subject of an experimental study of future engineers and young border guards.

\section{Experimental study of the readiness of border guards for professional engineering activities}

For the purpose of experimental study of the peculiarities of personal readiness for professional engineering activity, we selected a set of methods and techniques, which included: observations, interviewing methods (questionnaires, interviews), testing. The sample consisted of: 100 cadets - future engineers of NASBGSU, 100 officers-engineers - graduates of the National Academy of the State Border Guard Service of Ukraine, for a term of up to 5 years of service and students of mechanical engineering of the city of Vinnytsia (100 persons). The study was conducted in 2018-2019. 
According to the methodology presented in ${ }^{8}$, the structure of motivation that encourages cadets-border guards and students of 2-3 courses to study at the HEI was researched. (Table 1). As can be seen from Table 1, there are some differences in the structure of motivation for choosing a profession among students of future mechanical engineers and cadets of NASBGSU. On the positive side, most young people consider studying at the HEI a condition for personal development (professional, intellectual, physical, strong-willed, etc.). However, such a group of motives is much more important in cadets than in students. As for the motivation of the prestige of the engineering profession, it is also much higher among the students of NASBGSU, compared with the students of civil defense.

\section{Features of development in youth motivation to choose the profession of engineer}

\begin{tabular}{|l|c|c|}
\hline \multirow{2}{*}{ Groups of motives } & \multicolumn{2}{|c|}{ Youth category in\% } \\
\cline { 2 - 3 } & $\begin{array}{c}\text { Mechanical Engineering } \\
\text { students } \\
(\mathbf{n = 1 0 0 )}\end{array}$ & $\begin{array}{c}\text { Students-border } \\
\text { guards } \\
(\mathbf{n = 1 0 0})\end{array}$ \\
\hline Socially significant & 35 & 42 \\
\hline $\begin{array}{l}\text { Motives for improving the } \\
\text { personality }\end{array}$ & 54 & 68 \\
\hline $\begin{array}{l}\text { Motives for the prestige } \\
\text { of the profession }\end{array}$ & 26 & 54 \\
\hline Material motives & 19 & 42 \\
\hline Secondary motives & 26 & 32 \\
\hline
\end{tabular}

Civil engineering (profession - mechanical engineer) does not enjoy high prestige among young people today, which is probably due to their awareness of employment problems, future career prospects etc. Future border guards-engineers are slightly higher than those of civilians are, and have material motives, due to some differences in their payment. The remuneration of border guards is far higher than that of civil engineers today.

8 Tomchuk M. I., Matohniuk L. O. (2012). Formuvannya psykholohichnoyi hotovnosti osobystosti do inzhenernoyi diyal'nosti na zanyattyakh $z$ matematyky [Formation of psychological readiness of an individual for engineering activities in mathematics classes]. Vinnitsa: Publisher FOP Rogalskaya I. O. [in Ukrainian] 
The study examined the integral professionally important qualities of the personality of the border guard-engineers, namely their ability to creative self-realization, communicative competence, and the adequacy of professional self-esteem (Table 2).

The presence of one or another professionally important quality in the structure of the professionalism of an engineer does not indicate that the professional activity will be successful. These qualities should be developed by cadets in the educational process of NASBGSU and should have at the beginning of the service a level of development sufficient for professional activity.

Table 2

Formation of professionally important qualities in cadets (2-3rd years of studying) and young officers of border guard-engineers

\begin{tabular}{|c|c|c|c|c|c|}
\hline \multirow{2}{*}{$\begin{array}{c}\text { Professionally } \\
\text { important } \\
\text { qualities }\end{array}$} & \multirow{2}{*}{$\begin{array}{c}\text { Category } \\
\text { persons }\end{array}$} & \multicolumn{4}{|c|}{$\begin{array}{c}\text { Levels of development } \\
\text { of personality PVA (in \%) }\end{array}$} \\
\hline & & Low & Average & High & Very high \\
\hline \multirow{2}{*}{$\begin{array}{l}\text { Ability to } \\
\text { creative } \\
\text { self-realization }\end{array}$} & $\begin{array}{l}\text { The } \\
\text { cadets }\end{array}$ & 52 & 38 & 10 & 0 \\
\hline & $\begin{array}{l}\text { Young } \\
\text { officers }\end{array}$ & 10 & 62 & 12 & 16 \\
\hline \multirow{2}{*}{$\begin{array}{l}\text { Communicative } \\
\text { competence }\end{array}$} & $\begin{array}{l}\text { The } \\
\text { cadets }\end{array}$ & 14 & 44 & 30 & 12 \\
\hline & $\begin{array}{l}\text { Young } \\
\text { officers }\end{array}$ & 4 & 50 & 30 & 16 \\
\hline \multirow{2}{*}{$\begin{array}{c}\text { Adequacy } \\
\text { of professional } \\
\text { self-assessment }\end{array}$} & $\begin{array}{l}\text { The } \\
\text { cadets }\end{array}$ & 30 & 44 & 22 & 4 \\
\hline & $\begin{array}{l}\text { Young } \\
\text { officers }\end{array}$ & 4 & 32 & 54 & 10 \\
\hline
\end{tabular}

However, as can be seen from Table 2, the cadets' level of formation of such PITs is much lower than that of the young officers who actually serve at the border. It has been found that in the course of training at NASBGSU the cadets do not fully develop their abilities for creative selfrealization. This is especially true of junior cadets, whose rigorous statutory determination of activities at the academy does not fully create the space for the creative development and self-development of a future border guard-engineer officer. The cadets do not have the skills of creative 
self-realization, which should be laid in the process of circle, research, scientific and technical activity in HEI.

Almost every third border guard-cadet has also been found to have a low level of professional self-assessment adequacy. This is probably due to the lack of awareness of young men and women about the real service at the border, its identity requirements. Somewhat higher is the adequacy of professional self-assessment after the internship of cadets at regional offices of the State Border Guard Service. With the inclusion of the individual in the real engineering activity at the border, there are significant changes in the development and self-assessment of their PITs.

An important task of our study was to study the ideas of cadets and young border guards regarding professionally important qualities for the performance of their service tasks (the results of their study are shown in Table 3).

Table 3

Notions of future and young officers about the professional qualities of a border guard-engineer, which are important for the performance of their tasks

\begin{tabular}{|l|l|c|c|}
\hline $\begin{array}{c}\text { № } \\
\mathbf{S} / \mathbf{n}\end{array}$ & $\begin{array}{c}\text { Professional important } \\
\text { qualities of an engineer-officer } \\
\text { of the State Border Guard } \\
\text { Service of Ukraine }\end{array}$ & $\begin{array}{c}\text { Percentage } \\
\text { of mentioning } \\
\text { cadets-border } \\
\text { guards }\end{array}$ & $\begin{array}{c}\text { Percentage } \\
\text { of mentioning } \\
\text { officers-border } \\
\text { guards }\end{array}$ \\
\hline 1 & Technical and abstract thinking & 87 & 70 \\
\hline 2 & Memory & 56 & 52 \\
\hline 3 & Communication & 40 & 60 \\
\hline 4 & Attentiveness & 74 & 52 \\
\hline 5 & Self-regulation & 48 & 76 \\
\hline 6 & Responsibility & 65 & 88 \\
\hline 7 & Stress resistance & 44 & 85 \\
\hline 8 & Persistence & 34 & 72 \\
\hline 9 & Purposefulness & 42 & 76 \\
\hline 10 & Organizational skills & 74 \\
\hline
\end{tabular}

Border guards consider it important to be more strong-willed than intelligent when deciding on border guard tasks. The cadets have the willpower qualities, the ability of the officer's personality to self- 
regulation do not give much advantage. Realistically, more extreme than studying at the academy, the border guard service makes significant adjustments to the border guards' perceptions of the requirements it applies to all areas of the individual. Therefore, if the cadets ranked the intellectual qualities of the personality, then the young officers of the border guards ranked strong-willed qualities, qualities of self-regulation.

\section{CONCLUSIONS}

It can be concluded that in the conditions of training of cadets at the Academy it is extremely important to create situations in which they could create adequate ideas about professional activity at the border and the importance of making informed, volitional decisions by officers in various situations at the border.

\section{SUMMARY}

The article is devoted to theoretical and experimental analysis of the peculiarities of the development of border guard engineers' professional readiness to solve their official tasks. A comparative analysis of the levels of development of individual components of professionalism in young men and women studying at the academy and in humanitarian HEA has been carried out. It is argued that an indicator of the professionalism of a personality is its readiness for professional activity. That is why the authors present the results of an experimental study of individual indicators of the development of the readiness of border guards engineers to solve their tasks: motives, volitional traits, qualities, etc. The psychological analysis of the activity of the officers-border guards of the engineering direction is carried out. The special task of training border guards is to teach them the features of the organization, the operation of weapons and equipment, and the order and analysis of the reliability of basic models of border equipment. As a result of the survey of the graduates of the Academy, the features of the professional activity of frontier engineers (mental load, creativity, experience and knowledge, organization, initiative, independence, responsibility) are highlighted; the structure of motivation that encourages cadets, border guards and students of 2-3 courses to study at the WHO has been studied; Integrated professionally important qualities of the frontier engineer's personality were studied, namely their ability for creative self-realization, communicative competence, and adequacy of professional self-esteem. It is proved that in the conditions of training of cadets in the academy it is 
extremely important to create situations in which they would form adequate ideas about professional activity at the border and the importance of making informed, volitional decisions by officers in various situations at the border.

\section{REFERENCES}

1. Bodrov V.A. (2007). Psykholohycheskye osnovy professyonal'noy deyatel'nosty [Psychological bases of professional activity]. Moscow: PERSE Publ. [in Russian]

2. Zeer E. F. (2009). Psykholohyya professyonal'noho obrazovanyya [Psychology of Professional Education]. Moscow: IT Academy Publ. [in Russian]

3. Povarenkov Yu. P. (2002). Psykholohycheskoe soderzhanye professyonal'noho stanovlenyya cheloveka [Psychological content of professional formation of a person]. Moscow: Publishing House of URAO. [in Russian]

4. Rubalka V. V. (2014). Psykholohiya ta pedahohika pratsi osobystosti: vid obdarovanosti dytyny do maysternosti dorosloho [Psychology and pedagogy of the work of the individual: from the gifted child to the skill of the adult]. Kyiv: Institute of Gifted Child Publ. [in Ukrainian]

5. Tomchuk M. I., Matohniuk L. O. (2012). Formuvannya psykholohichnoyi hotovnosti osobystosti do inzhenernoyi diyal'nosti na zanyattyakh $z$ matematyky [Formation of psychological readiness of an individual for engineering activities in mathematics classes]. Vinnitsa: Publisher FOP Rogalskaya I. O. [in Ukrainian]

6. Shadrikov V. D. (1996). Psykholohyya deyatel'nosty $y$ sposobnosty cheloveka [Psychology of human activity and ability]. Moscow: Logos Publ. [in Russian]

\section{Information about the author: Mykhailo Tomchuk}

Doctor of Psychological Sciences, Professor, Senior Researcher of the Research Department National Academy of the State Border Guard Service of Ukraine named after Bohdan Khmelnytskyi 46, Shevchenko str., Khmelnytskyi, 29003, Ukraine ORCID ID: orcid.org / 0000-0002-4508-1495

E-mail: tomchukmi@gmail.com 